\title{
ALKALINE LAMPROPHYRES FROM THE SOKLI COIMPLEX, NORTHERN FINLAND
}

\author{
H. VARTIAINEN, P. KRESTEN and Y. KAFKAS
}

\begin{abstract}
VARTIAINEN, H.; KRESTEN, P. and KAFKAS, Y. 1978: Alkaline lamprophyres from the Sokli complex, northern Finland. Bull. Geol. Soc. Finland 50: 59-68.

Alkaline lamprophyric dykes in the Sokli carbonatite complex closely resemble kimberlites in mineralogical and chemical composition. Mineralogically, they differ from kimberlites by the presence of high-manganese ilmenite and richterite, and the absence of highpressure minerals and cognate inclusions. They most likely represent altered kimberlites with a high degree of crustal contamination and carbonatite admixture.

H. Vartiainen, Rautaruukki Co, SF-96100 Rovaniemi 10, Finland. P. Kresten, Geological Survey of Sweden, S-10405 Stockholm, Sweden.

Y. Kafkas, Department of Mineralogy, Box 6801, S-113 86 Stockholm, Sweden.
\end{abstract}

\section{Introduction}

The geology of the Sokli carbonatite complex in northern Finland has been briefly discussed by Paarma (1970), and Vartiainen and Woolley (1974). Lamprophyric dykes occur both within the complex and in the wall-rock. Diamond drill cores are the main source of observations owing to the absence of outcrops.

The width of the dykes varies from a few millimetres to some metres. The average thickness of 246 dykes studied is 52 centimetres. The length of the dykes could not be estimated. In drill sections from the carbonatite body, lamprophyric dykes constitute between 0.6 and $8.7 \%$ by volume; corresponding figures for the wall-rock are
1.1. to $5.8 \%$ (Fig. 1). They commonly form dyke swarms (Fig. 2A), with dips ranging from near horizontal to almost vertical. All observations indicate a random pattern of intrusions, rather than a regular one as proposed by von Eckermann $(1948,1958)$ for the Alnö dykes.

Dyke emplacement is obviously one of the latest events at Sokli. Within the carbonatite, dykes are assimilated and brecciated by late sövite; all dykes show veinlets of calcite and dolomite.

\section{Petrography}

The Sokli dykes are divided into four petrographic groups (Table 1) with different 


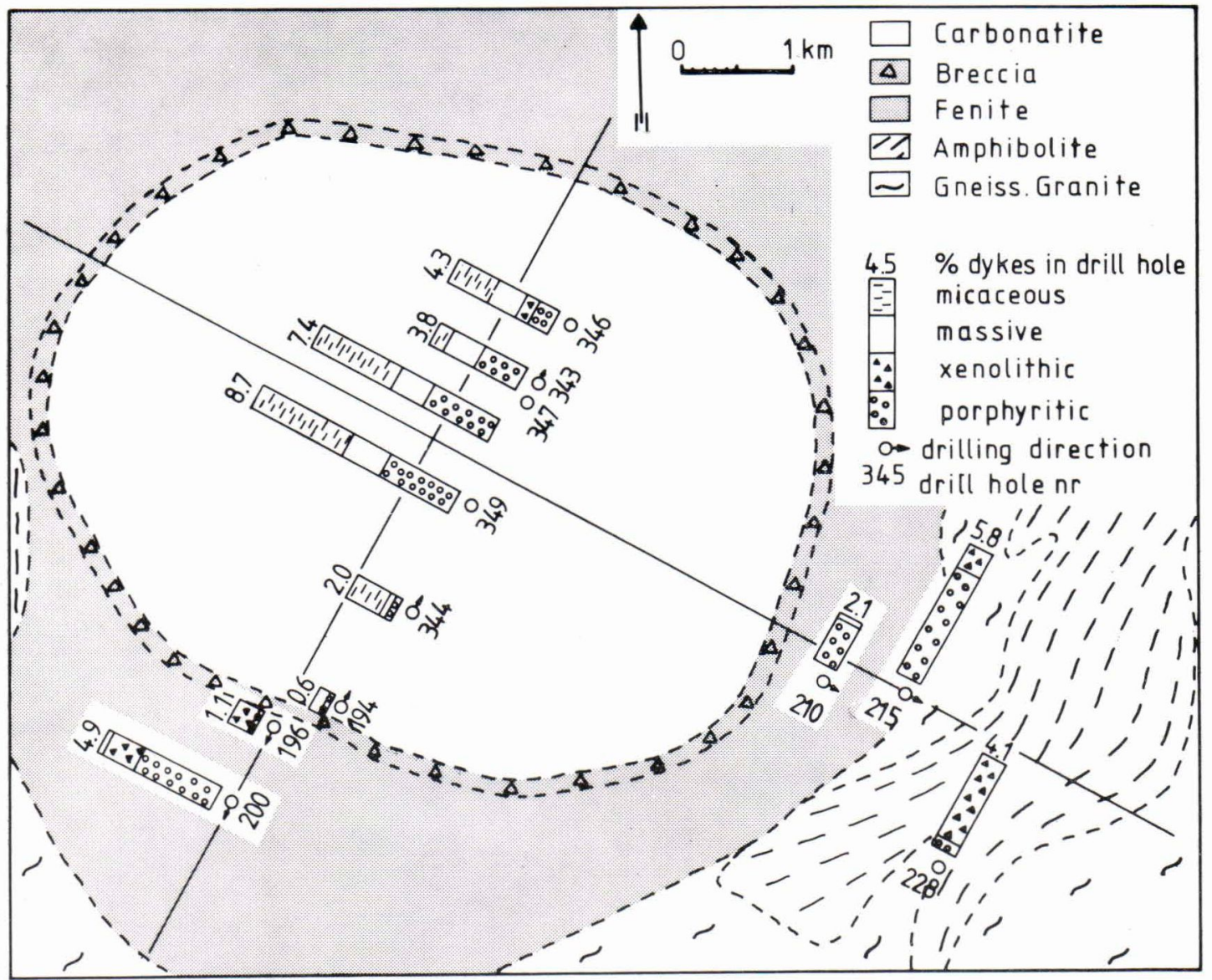

Fig. 1. Geological sketch map of the Sokli complex, showing the relative distribution of dyke rocks.

Table 1. Characteristics of Sokli dykes.

\begin{tabular}{|c|c|c|c|}
\hline Type & Colour & Flow textures & Chilled margins \\
\hline Porphyritic & $\begin{array}{l}\text { green, grayish } \\
\text { and dark green }\end{array}$ & common & common \\
\hline Xenolithic & gray, grayvish green & common & common \\
\hline Massive & green, grayish green & rare & rare \\
\hline Micaceous & green, reddish brown & rare & rare \\
\hline
\end{tabular}

modes of occurrence. Micaceous dykes occur only within the carbonatite plug (Fig. 1), where massive dykes also are abound; these two varieties account for more than $50 \%$ of the dykes within the carbonatite. Porphyritic and xenolithic dykes are predominant in the wall-rock (Fig. 1).
Colour and texture vary considerably within one dyke, giving the rock a very heterogeneous appearance (Fig. 2C). Dyke swarms are usually made up of dykes of the same petrographic group. The mineralogical characteristics of the various groups are given in Table 2. 


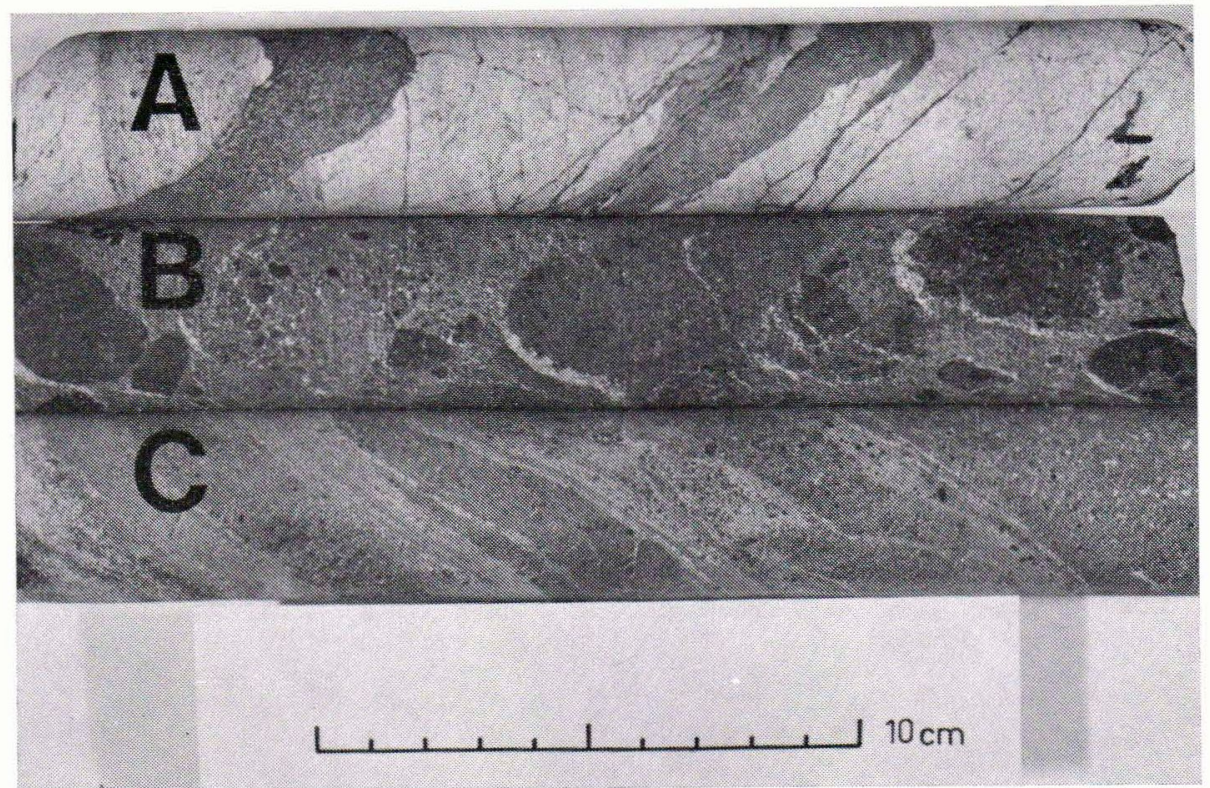

Fig. 2. A. Micaceous dyke swarm cutting sövite. DH 368/259.5. B. Xenolithic dyke with phoscorite and olivinite fragments, surrounded by calcite reaction rims. DH 366/59.5. C. Semi-banded structure in composite dyke. DH 366/89.0.

Table 2. Mineralogical compositions of Sokli dykes (in vol.- $\%$ ).

\begin{tabular}{|c|c|c|c|c|c|c|c|}
\hline Sample & -0001 & -0003 & -0004 & -0005 & -0007 & -0002 & $\mathrm{Rm} 852$ \\
\hline \multicolumn{8}{|l|}{ Phenocrysts } \\
\hline Olivine, fresh & 26.0 & & & & 4.5 & & \\
\hline \multicolumn{8}{|l|}{ Olivine, altered: } \\
\hline serpentine & 3.0 & 3.5 & 8.5 & 13.5 & & 7.5 & \\
\hline bowlingite & 0.5 & & 8.5 & 6.0 & & & \\
\hline iddingsite & & 11.0 & & & 2.5 & & \\
\hline carbonate & 0.5 & 19.0 & 0.5 & 2.0 & & & \\
\hline phlogopite & 0.5 & 2.5 & 0.5 & 0.5 & & & \\
\hline clinohumite & 3.0 & & & & & & \\
\hline opaques & 0.5 & 1.0 & 0.5 & 0.5 & & & \\
\hline Phlogopite & 0.5 & & 13.0 & 2.0 & 3.5 & & \\
\hline Richterite & 1.5 & & & 1.0 & & & \\
\hline Calcite & & & & 2.0 & & & \\
\hline Opaques & & & 4.5 & & 9.5 & & \\
\hline Xenoliths & & & & & 23.0 & & \\
\hline \multicolumn{8}{|l|}{ Matrix } \\
\hline Phlogopite & 16.0 & 21.0 & 13.0 & 22.0 & 15.0 & 27.0 & 68.2 \\
\hline Calcite & 20.0 & 21.0 & 24.5 & 27.0 & 15.5 & 24.0 & 21.3 \\
\hline Serpentine & & 2.5 & 3.5 & 6.0 & & 3.0 & \\
\hline Iddingsite & 7.5 & 6.0 & & & 6.5 & 3.0 & \\
\hline Richterite & 7.5 & & & 8.5 & 5.5 & 25.0 & \\
\hline Apatite & 4.0 & & & & 3.0 & 0.5 & \\
\hline Opaques & 9.0 & 13.5 & 23.0 & 9.5 & 11.5 & 10.0 & 10.5 \\
\hline
\end{tabular}

Samples: -0001 porphyritic $\begin{array}{ll}-0003 & \text { " } \\ -0004 & \\ -0005 & \end{array}$
Samples: $\begin{aligned}-0007 & \text { xenolithic } \\ -0002 & \text { massive }\end{aligned}$

Rm 852 micaceous 


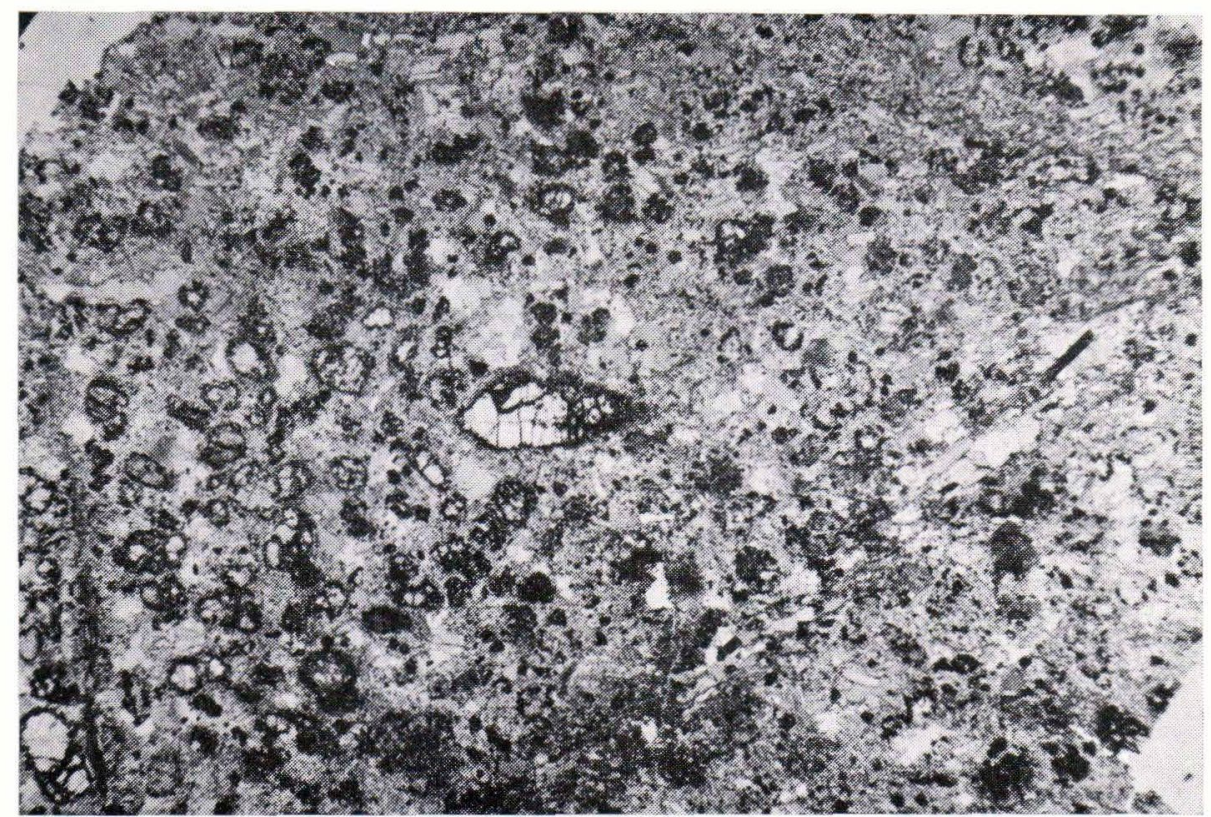

Fig. 3. A. Porphyritic dyke with fresh olivine phenocrysts, rimmed and fracture-filled by magnetite. DH 2/192.2.

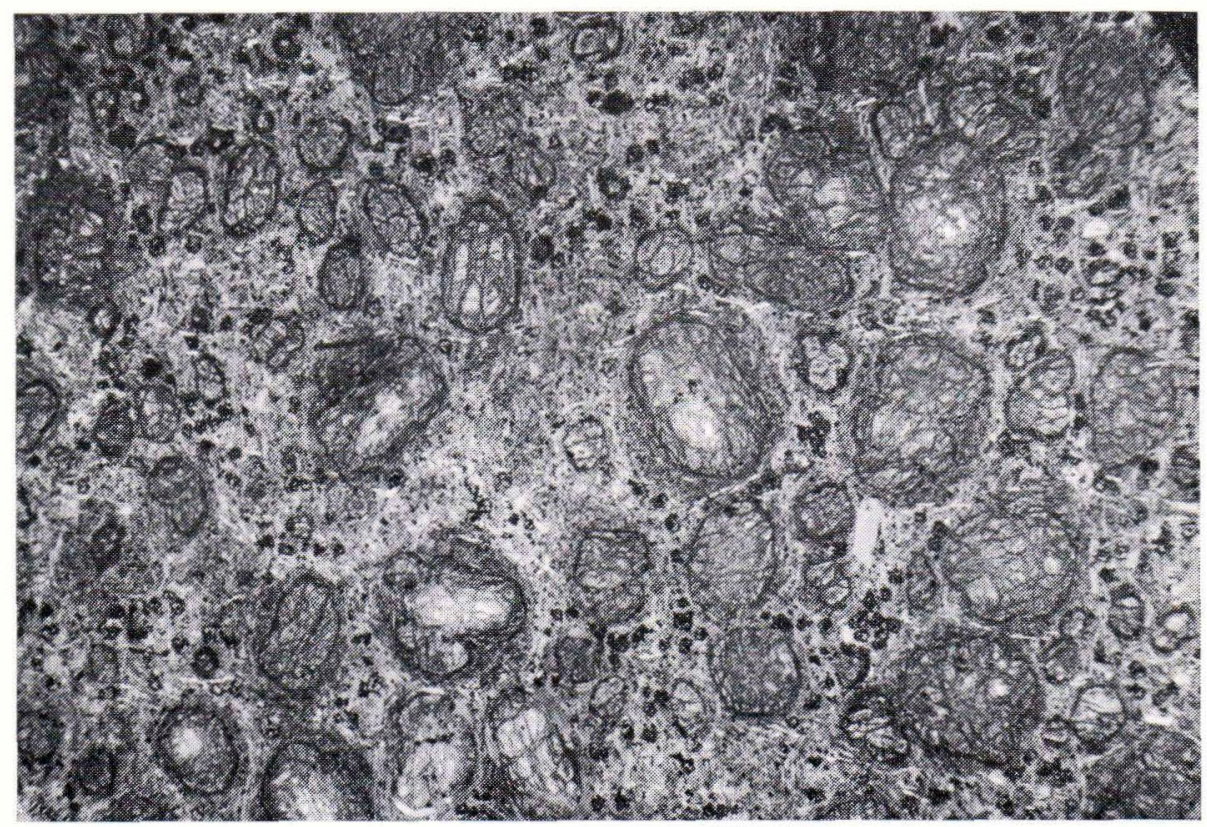

Fig. 3. B. Porphyritic dyke, with olivine phenocrysts completely altered into serpentine, bowlingite and carbonate. DH $343 / 207.5$ ( $\mathrm{Nr}-0003)$. 
Table 3. Microprobe analyses.

\begin{tabular}{|c|c|c|c|c|c|c|c|}
\hline No. & 1 & 2 & 3 & 4 & 5 & 6 & 7 \\
\hline $\mathrm{SiO}_{2}$ & 40.9 & 42.1 & 41.5 & 53.3 & - & - & - \\
\hline $\mathrm{TiO}_{2}$ & 0.05 & 0.05 & 0.06 & 0.63 & 52.0 & 52.7 & 51.3 \\
\hline $\mathrm{ZrO}_{2}$ & 0.05 & 0.05 & 0.05 & - & - & - & 一 \\
\hline $\mathrm{Nb}_{2} \mathrm{O}_{5}$ & 0.07 & 0.05 & 0.05 & - & - & - & - \\
\hline $\mathrm{Al}_{2} \mathrm{O}_{3}$ & 0.05 & 0.05 & 0.05 & 1.65 & 0.06 & 0.08 & 0.08 \\
\hline $\mathrm{Cr}_{2} \mathrm{O}_{3}$ & 0.05 & 0.05 & 0.05 & - & 0.02 & 0.01 & 0.07 \\
\hline $\mathrm{FeO}$ (tot.) & 8.5 & 8.0 & 5.4 & 2.6 & 38.3 & 35.0 & 40.5 \\
\hline $\mathrm{NiO}$ & 0.38 & 0.46 & 0.05 & - & - & - & - \\
\hline $\mathrm{MnO}$ & 0.10 & 0.11 & 0.85 & 0.11 & 3.74 & 3.97 & 4.45 \\
\hline $\mathrm{MgO}$ & 49.3 & 48.3 & 53.2 & 22.4 & 5.9 & 7.7 & 5.1 \\
\hline $\mathrm{CaO}$ & 0.19 & 0.13 & 0.13 & 8.4 & - & - & 一 \\
\hline $\mathrm{Na}_{2} \mathrm{O}$ & 0.05 & 0.05 & 0.05 & 5.5 & - & - & 一 \\
\hline $\mathrm{K}_{9} \mathrm{O}$ & 0.05 & 0.05 & 0.05 & 0.8 & - & - & - \\
\hline Total & 99.74 & 99.45 & 101.48 & 95.39 & 100.42 & 99.46 & 101.50 \\
\hline \multicolumn{8}{|c|}{$\begin{array}{l}\text { 1. Olivine phenocryst, porphyritic dyke }(-0001), \mathrm{DH} 347 / 403.0 \\
\text { 2. Olivine, olivinite of Tulppio, trench } 2(980-2145) \\
\text { 3. Olivine, phoscorite, DH } 260 / 77.0 \\
\text { 4. Richterite phenocryst, porphyritic dyke }(-0001), \mathrm{DH} 347 / 403.0 \\
\text { 5. Ilmenite, average of } 8 \text {, porphyritic dyke }(-0001), \mathrm{DH} 347 / 403.0 \\
\text { 6. Ilmenite, average of } 8 \text {, porphyritic dyke (Rm 107), DH } 2 / 192.2 \\
\text { 7. Ilmenite, average of } 8 \text {, massive dyke }(-0002), \mathrm{DH} 343 / 145.7\end{array}$} \\
\hline
\end{tabular}

Olivine occurs as phenocrystal phase, constituting between $\overline{2} 0$ and $40 \%$ by volume of the rock (Table 2). The size of the phenocrysts varies from 0.5 to $4 \mathrm{~mm}$. The phenocrysts are usually rounded (Fig. 3), rarely subhedral. Euhedral grains are very exceptional. Secondary alteration into a variety of minerals is common (Table 1, Fig. 3B); fresh olivines occur only in porphyritic and xenolithic dykes (Fig. 3A). Alteration has been most intense in micaceous dykes, which preserve only faint outlines of the original phenocrysts.

The chemical composition of the olivines resembles that of olivine from the Tulppio ultramafic massif close to the complex (Table $3)$. Both have higher $\mathrm{NiO}$, slightly higher $\mathrm{FeO}$, and lower $\mathrm{MnO}$ contents than olivine from phoscorite (Table 3). At present, the number of analyses is still insufficient to allow a more detailed discussion.

Phlogopite occurs as both phenocrystal phase (size $0.5-5 \mathrm{~mm}$ ), and matrix con- stituent. Pleochroism is normal ( $\mathrm{Z}=$ yellowish or greenish brown, $\mathrm{Y}=\mathrm{X}=$ pale yellow to colourless). Phenocrysts exhibit slight compositional zoning, and are sometimes rimmed by late-stage phlogopite showing reverse pleochroism $(\mathrm{X}=$ bright orange, $\mathrm{Y}=\mathrm{Z}=$ pale yellow to colourless).

Calcite if found as corroded subhedral phenocrysts, or aggregations of two or more grains. This might indicate that calcite is not primary magmatic but a xenolithic constituent derived from sövite.

Richterite occurs as colourless phenocrysts, 0.5 to $1.5 \mathrm{~mm}$ long, which are often ragged and replaced by calcite. Chemical analysis (Table 3) yields the following formula: $\left(\mathrm{Na}_{.91} \mathrm{~K}_{.14}\right) \quad\left(\mathrm{Na}_{.61} \mathrm{Ca}_{1.29} \mathrm{Fe}_{.10}\right) \quad\left(\mathrm{Mg}_{4.78} \mathrm{Mn}_{.01} \mathrm{Fe}_{.21}\right)$ $\left(\mathrm{Si}_{7.62} \mathrm{Al}_{.28} \mathrm{Ti}_{.07}\right) \mathrm{O}_{22}(\mathrm{OH})_{2}$, with $\mathrm{A}=1.05, \mathrm{X}=$ $=2.00, \mathrm{Y}=5.00, \mathrm{Z}=7.97$.

$\mathrm{X}$-ray powder diffraction of sample -0002 (Table 2) proved the mineral to be richterite, with the following strongest reflections $(\AA)$ : 
8.35 (100), 3.131 (80), 3.270 (60), 2.810 (40), $4.80(30)$.

Magnetite phenocrysts are rounded, and measure up to $15 \mathrm{~mm}$ in diameter.

Xenoliths are rounded to subrounded (Fig. 2B), measuring 1 to $5 \mathrm{~cm}$ across. Xenolithic dykes within the carbonatite contain fragments of phoscorite, sövite and olivinite; those from the wall-rock mainly sövite and fenite. A more detailed study of the xenoliths is lacking.

The matrix generally constitutes 60 to $75 \%$ by volume of the dykes; for massive and micaceous dykes up to $100 \%$. Its principal constituents are fairly similar for all petrographic groups (Table 2). The average grain size of matrix minerals is below 0.1 $\mathrm{mm}$.

The sequence of crystallization is opaques - phlogopite and calcite - richterite. Flow textures of the rocks are outlined by preferred orientation of phlogopite and richterite.

Calcite is found in anhedral grains; richterite is commonly euhedral. Opaques occur as small grains: disseminated magnetite may exceptionally comprise more than $50 \%$ of the matrix.

Ilmenite occurs in minor amounts only; it is most common in porphyritic and some micaceous dykes. The chemical composition of ilmenite is characterized by fairly high contents of $\mathrm{MnO}$ and moderate contents of $\mathrm{MgO}$ (Table 3). Compared with ilmenites from related rocks, the Sokli ilmenites constitute a group of their own (Fig. 4). Ilmenites from kimberlites are characterized by low $\mathrm{MnO}$ contents and high $\mathrm{MgO}$ contents. The literature gives only two analyses of ilmenites deviating from this pattern: a high $\mathrm{MnO}-$ low $\mathrm{MgO}$ ilmenite from Monastery Mine (Mitchell et al. 1973), and an ilmenite from Premier Mine (Frick 1970), which is very similar in composition to the Sokli ilmenites (Fig. 4). An ilmenite from alnöite at Alnö

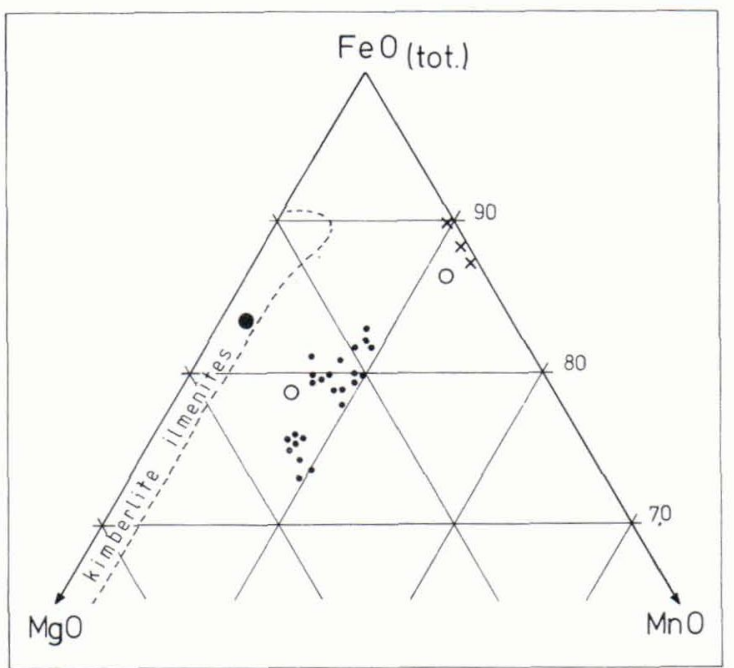

Fig. 4. Composition of Sokli ilmenites (dots), compared with ilmenites from Fen (crosses), Alnö (filled circle) and kimberlites (open circles, and beyond dashed line).

(von Eckermann 1974) is very similar to kimberlite ilmenites; ilmenites from damkjernites at Fen (Griffin and Taylor 1975) have very low $\mathrm{MgO}$ contents, similar to the Monastery Mine sample (Fig. 4).

Ilmenites from kimberlites, alnöites and related rocks can thus be divided into three groups (Fig. 4):

1) low manganese: most kimberlites, alnöite (Alnö)

2) high manganese, low magnesium: damkjernite (Fen), Monastery Mine

3) high manganese, moderate magnesium: Sokli dykes, Premier Mine

More data are needed for a detailed discussion of the possible petrogenetic implications of this pattern. A more shallow, lowpressure origin of the high-manganese ilmenites seems plausible.

\section{Chemical composition}

Six whole-rock analyses of Sokli dykes are given in Table 4. The Sokli dykes show 
Table 4. Chemical analyses of Sokli dykes.

\begin{tabular}{|c|c|c|c|c|c|c|}
\hline Sample & -0001 & -0003 & -0004 & -0005 & -0007 & -0002 \\
\hline $\mathrm{SiO}_{0}$ & 27.0 & 21.8 & 28.7 & 27.1 & 19.1 & 30.2 \\
\hline $\mathrm{TiO}_{2}$ & 2.3 & 3.5 & 3.6 & 2.9 & 2.9 & 2.1 \\
\hline $\mathrm{Al}_{2} \mathrm{O}_{3}$ & 2.0 & 2.4 & 4.1 & 1.9 & 2.2 & 3.9 \\
\hline $\mathrm{Fe}_{2} \mathrm{O}_{3}$ & 8.2 & 7.0 & 11.8 & 7.4 & 20.5 & 8.2 \\
\hline $\mathrm{FeO}$ & 6.7 & 7.4 & 6.5 & 6.0 & 11.1 & 6.2 \\
\hline $\mathrm{MnO}$ & 0.37 & 0.29 & 0.27 & 0.26 & 0.52 & 0.37 \\
\hline $\mathrm{MgO}$ & 20.7 & 17.6 & 16.6 & 20.3 & 17.0 & 18.4 \\
\hline $\mathrm{CaO}$ & 13.2 & 13.8 & 15.4 & 11.1 & 10.5 & 12.7 \\
\hline $\mathrm{Na}_{2} \mathrm{O}$ & 1.2 & 1.2 & 0.4 & 1.1 & 0.7 & 2.9 \\
\hline $\mathrm{K}_{2} \mathrm{O}$ & 2.2 & 3.6 & 2.5 & 1.5 & 2.3 & 2.0 \\
\hline $\mathrm{H}_{2} \mathrm{O}+105$ & 2.7 & 1.9 & 2.4 & 3.9 & 1.8 & 2.3 \\
\hline $\mathrm{H}_{2} \mathrm{O}-105$ & 0.5 & 0.5 & 0.7 & 1.2 & 0.4 & 0.3 \\
\hline $\mathrm{P}_{2} \mathrm{O}_{5}$ & 2.5 & 1.06 & 0.99 & 0.18 & 2.5 & 0.80 \\
\hline $\mathrm{CO}_{2}$ & 9.5 & 17.6 & 4.6 & 14.5 & 8.4 & 9.6 \\
\hline $\mathrm{F}$ & 0.55 & 0.58 & 0.32 & 0.27 & 0.49 & 0.47 \\
\hline $\mathrm{S}$ & 0.66 & 0.12 & 0.11 & 0.13 & 0.18 & 0.09 \\
\hline $\mathrm{BaO}$ & 0.10 & 0.08 & 0.16 & 0.08 & 0.14 & 0.16 \\
\hline Sum & 100.38 & 100.43 & 99.15 & 99.82 & 100.73 & 100.69 \\
\hline$-\mathrm{O}=\mathrm{F}, \mathrm{S}$ & 0.40 & 0.27 & 0.16 & 0.15 & 0.26 & 0.22 \\
\hline Total & 99.98 & 100.16 & 98.99 & 99.67 & 100.47 & 100.47 \\
\hline \multicolumn{7}{|c|}{ Molec. norm. } \\
\hline Or & 10.93 & 9.82 & - & 8.99 & 1.14 & 6.98 \\
\hline $\mathrm{Ab}$ & - & - & - & 1.44 & - & - \\
\hline An & - & - & 2.04 & 一 & - & - \\
\hline $\mathrm{Lc}$ & - & 2.58 & 11.77 & - & 8.49 & 3.76 \\
\hline $\mathrm{Ne}$ & - & - & 1.86 & - & 一 & 4.82 \\
\hline Ac & 8.96 & 8.95 & - & 7.04 & 5.20 & 13.70 \\
\hline $\mathrm{Ks}$ & 0.58 & 2.27 & - & - & 0.44 & - \\
\hline $\mathrm{Di}$ & - & - & 15.61 & - & - & - \\
\hline Hy & 0.74 & - & - & 18.48 & - & - \\
\hline Ol & 35.12 & 21.06 & 24.36 & 14.58 & 25.35 & 34.88 \\
\hline $\mathrm{Cs}$ & - & - & 5.56 & - & - & - \\
\hline Mt & 7.41 & 5.67 & 11.17 & 7.35 & 27.02 & 4.98 \\
\hline $\mathrm{Hm}$ & - & - & 4.28 & - & - & - \\
\hline Il & 4.37 & 6.65 & 6.94 & 5.58 & 5.49 & 3.97 \\
\hline Ap & 5.93 & 2.51 & 2.38 & 0.43 & 5.90 & 1.89 \\
\hline $\mathrm{Fr}$ & 0.67 & 1.00 & 0.48 & 0.53 & 0.55 & 0.81 \\
\hline $\operatorname{Pr}$ & 1.24 & 0.22 & 0.21 & 0.25 & 0.33 & 0.17 \\
\hline $\mathrm{Cc}$ & 16.91 & 20.93 & 10.63 & 19.03 & 12.21 & 19.76 \\
\hline $\mathrm{Mg}$ & 3.98 & 16.11 & - & 12.13 & 5.75 & 1.67 \\
\hline
\end{tabular}

Analyses by the Geological Survey of Sweden

higher contents of $\mathrm{TiO}_{2}, \mathrm{FeO}$ (total), $\mathrm{MnO}$, $\mathrm{Na}_{2} \mathrm{O}$ and $\mathrm{CO}_{2}$, but lower contents of $\mathrm{SiO}_{2}$, $\mathrm{MgO}$ and $\mathrm{H}_{2} \mathrm{O}^{+}$than do average kimberlites (Dawson 1967). They differ from the damkjernites at Fen (Griffin and Taylor 1975) by higher contents of $\mathrm{FeO}$ (total), $\mathrm{MgO}$ and $\mathrm{CO}_{2}$, and lower contents of $\mathrm{SiO}_{2}, \mathrm{TiO}_{2}$ and $\mathrm{Al}_{2} \mathrm{O}_{3}$. The Sokli dykes have higher contents of $\mathrm{FeO}$ (total), $\mathrm{MnO}, \mathrm{Na}_{2} \mathrm{O}$ and $\mathrm{CO}_{2}$, and lower con- tents of $\mathrm{Al}_{2} \mathrm{O}_{3}$ and $\mathrm{CaO}$ than the alnöites and kimberlites from Alnö (von Eckermann, unpublished data).

The contents of selected trace elements are given in Table 5 . The data are consistent. with those reported for kimberlites (Dawson 1967, Mitchell and Brunfelt 1975, Fesq et al. 1975, Kable et al. 1975) and Alnö dykes (unpublished data). The rare-earth patterns for 


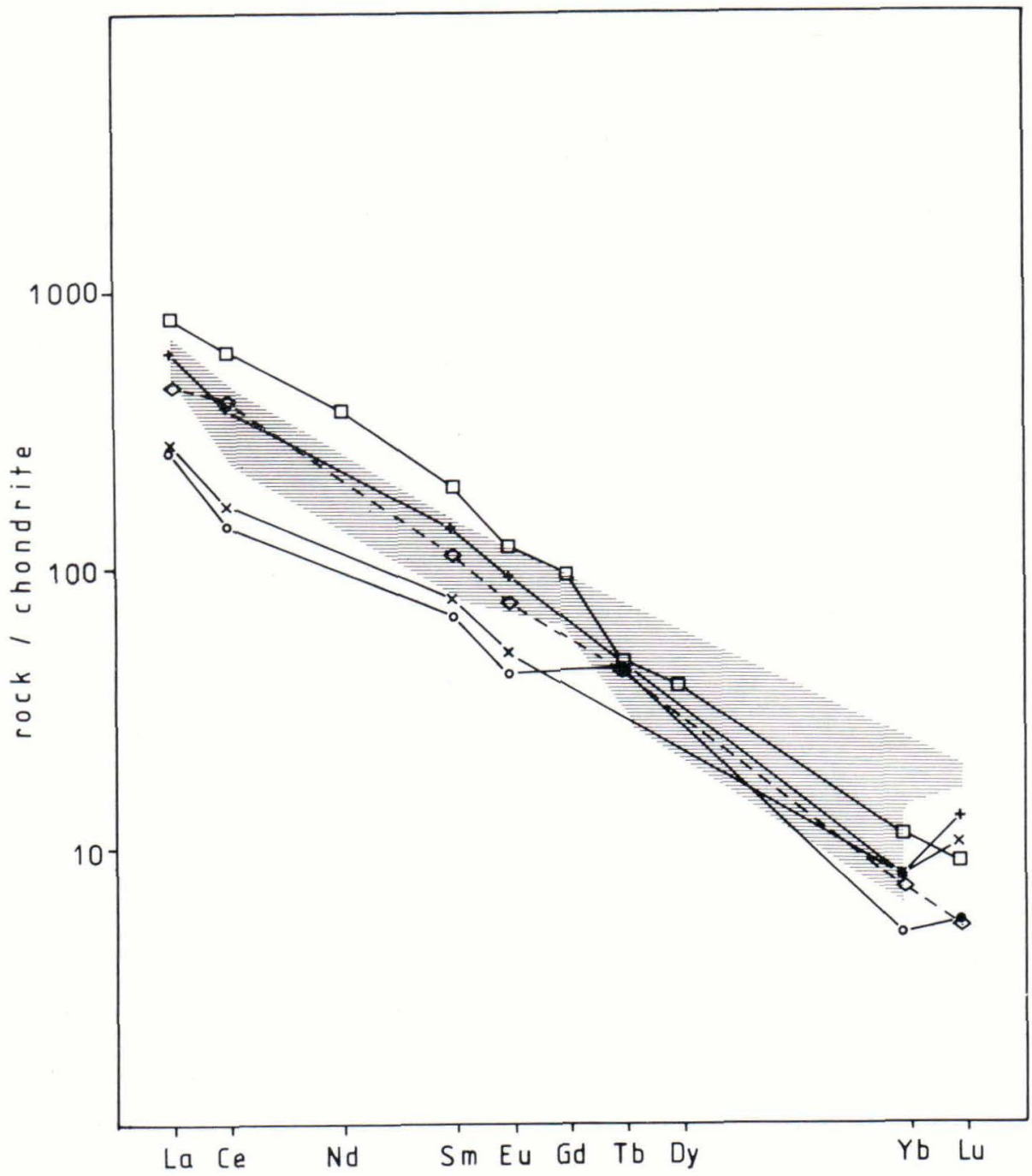

Fig. 5. Rare-earth patterns of Sokli rocks. Crosses sample -0001, inclined crosses: sample -0003, circles: sample —0007, squares: sövite, Sokli (Koljonen and Rosenberg, 1978), diamonds: kimberlite, Wesselton (Mitchell and Brunfelt, 1975), shade: alnöites, Alnö complex (unpubl.data).

the Sokli dykes (Fig. 5) are linear for porphyritic dykes; a xenolithic dyke shows a slight $\mathrm{Eu}$ anomaly. $\mathrm{La} / \mathrm{Yb}$ ratios range from 66 to 141, indicating a fairly high degree of differentiation, if parental magmas of basaltic or lherzolitic compositions are assumed.

$\mathrm{K} / \mathrm{Rb}$ ratios are in the range $235-431$, average 308 , which is higher than for alnöites and kimberlites (Kresten 1977), but within the range reported for damkjernites from Fen (Griffin and Taylor 1975).

In summary, it can be stated that the Sokli dykes represent carbonated alkaline lamprophyres with affinities to both alnöites and kimberlites. The calculated normative compositions (Table 4) indicate a possible dolomitic composition of the carbonate phase. Thermal analyses carried out on the samples 
Table 5. Selected trace elements in Sokli dykes (ppm)

\begin{tabular}{|c|c|c|c|c|c|c|}
\hline Sample & -0001 & -0003 & -0004 & -0005 & -0007 & -0002 \\
\hline $\mathrm{Zn}$ & 165 & 130 & 165 & 110 & 300 & 165 \\
\hline $\mathrm{Rb}$ & 36 & 100 & 75 & 38 & 50 & 43 \\
\hline $\mathrm{Sr}$ & 1300 & 900 & 1200 & 520 & 930 & 1100 \\
\hline $\mathrm{Nb}$ & 95 & 150 & 60 & 15 & 45 & 40 \\
\hline $\mathrm{Zr}$ & 275 & 345 & 150 & 130 & 650 & 300 \\
\hline $\mathrm{Cu}$ & 125 & 100 & 150 & 75 & 130 & 75 \\
\hline $\mathrm{Ni}$ & 400 & 350 & 300 & 700 & $<100$ & 370 \\
\hline $\mathrm{La}$ & 197 & 93 & & & 87 & \\
\hline $\mathrm{Ce}$ & 334 & 150 & & & 126 & \\
\hline $\mathrm{Sm}$ & 25.5 & 14.4 & & & 12.4 & \\
\hline $\mathrm{Eu}$ & 6.4 & 3.5 & & & 2.9 & \\
\hline $\mathrm{Tb}$ & & & & & 2.1 & \\
\hline $\mathrm{Yb}$ & 1.4 & 1.4 & & & 0.96 & \\
\hline $\mathrm{Lu}$ & 0.45 & 0.37 & & & 0.18 & \\
\hline $\mathrm{Sc}$ & 35 & 21 & & & 18 & \\
\hline Th & 27 & 37 & & & 14 & \\
\hline $\mathrm{U}$ & 10 & 8 & & & 6 & \\
\hline
\end{tabular}

Sr: atomic absorption, Th. Berg (Geological Survey of Sweden); Rb, Nb, Zr, Ni: X-ray fluorescence, Y. Kafkas; Cu: spectrophotometry, P. Kresten; REE, Sc, Th, U: instrum. neutron activation, P. Kresten.

did not confirm the presence of dolomite other than in very small amounts in samples -0003 and -0005 .

\section{Discussion}

The mineralogical compositions of the Sokli dykes compare well with those reported for kimberlites. Amphibole, however, seems to be very rare in kimberlites. Possibly tremolitic amphibole has been reported from two occurrences in Southern Africa (Lipelaneng, Nixon and Kresten 1973, Monastery Mine, Whitelock 1973), and one in Greenland (Emeleus and Andrews 1975). Actinolite has been reported as inclusions in diamond (Prinz et al. 1975), potassic richterite from nodules in kimberlite (Erlank and Finger 1970) and a possible kimberlite from Barkly West, South Africa (Erlank 1973).
Nevertheless, the absence of several minerals considered to be "critical» for kimberlite, such as (chrome) pyrope, chrome diopside and diamond, as well as the complete lack of ultramafic nodules in the material examined do not allow the term »kimberlite» to be used for the Sokli dykes. On the other hand, the Sokli dykes do not fit the present definition of the term "alnöite» (von Eckerman 1948); they do not contain melilite, and diopsidic or salitic pyroxene, which is common in alnöites.

It seems likely that the Sokli dykes derive from kimberlitic magma, from which some material (ultramafic nodules) had segregated and some (high-pressure minerals) had been re-equilibrated in a crustal magma pool. Crustal contamination and interaction with carbonatite magma must have played a key role in the petrogenesis of the Sokli dykes.

\section{References}

Dawson, J. B. (1967) Geochemistry and origin of kimberlite. In Wyllie, P. J. Ultramafic and related rocks, ed. by P. J. Wyllie. J. Wyllie and Sons. New York. 
Eckermann, H. V. (1948) The alkaline district of Alnö Island. Sveriges Geol. Unders. Ca 36, $176 \mathrm{p}$.

- (1958) The alkaline and carbonatitic dikes of the Alnö formation on the mainland northwest of Alnö Island. Kungl. Svenska Vetenskapsakad. Handl. IV, 7 (2). 61 p.

- (1974) The chemistry and the optical properties of some minerals of the Alnö alkaline rocks. Arkiev. Min. Geol. 5 (8): 93-210.

Emeleus, C. H. and Andrews, J. R. (1975) Mineralogy and petrology of kimberlite dyke and sheet intrusions and included peridotite xenoliths from South-West Greenland. Phys. Chem. Earth 9: 179-197.

Erlank, A. J. (1973) Kimberlite potassic richterite and the distribution of potassium in the upper mantle. Ext. Abstr., Int. Conf. Kimberlite Cape Town. 103-106.

Erlank, A. J. and Finger, L. W. (1970) The occurence of potassic richterite in a mica nodule from Wesselton Mine South Africa. Carnegie Inst. Wash. Yearb. 68: 442-443.

Fesq, H. W., Kable, E. J. D. and Gurney, J. J. (1975) Aspects of the geochemistry of kimberlites from Premier Mine, and other selected South African occurrences with particular reference to the rare earth elements. Phys. Chem. Erth 9: 687-708.

Frick, C. (1970) The mineralogy and petrology of kimberlite and its related inclusion, with special reference to Premier Mine. Unpubl. D.Sc. thesis, Fac. Sci., Univ. of Pretoria.

Griffin, W. L. and Taylor, P. N. (1975) The Fen damkjernite: Petrology of a »central-complex kimberlite». Phys. Chem. Earth 9: 163-178.

Kable, E. J. D., Fesq, H. W. and Gurney, J. J. (1975) The significance of the inter-element relationships of some minor and trace elements in South African kimberlites. Phys. Chem. Earth 9: 709-734.

Koljonen, T. and Rosengerg, R. (1978) Rare earth elements in carbonatites and related rocks as indications of their plate tectonic origin (in press).

Kreston, P. (1977) $\mathrm{K}, \mathrm{Rb}$ and $\mathrm{Cs}$ in carbonatites and associated rocks from central Sweden. Geol. Fören. Stockholm Förh. 9: 377-383.

Mitchell, R. H. and Brunfelt, A. O. (1975) Rare earth geochemistry of kimberlite. Phys. Chem. Earth 9: 671-686.

Mitchell, R. H., Carswell, D. A. and Brunfelt, A. O. (1973) Mineralogy and rare-earth geochemistry of an ilmenite-clinopyroxene xenolith from the Monastery Mine. Pp. 224-229 in Lesotho kimberlites, ed. by P. H. Nixon, LNDC, Maseru, Lesotho.

Nixon, P. H. and Kresten, P. (1973) Butha-Buthe dyke swarm and associated kimberlite blows. Pp. 197-206 in Lesotho kimberlites, ed. by P. H. Nixon, LNDC, Maseru, Lesotho.

Paarma, H. (1970) A new find of carbonatite in north Finland, the Sokli plug in Savukoski. Lithos 3: 129-133.

Prinz, M., Manson, D. V., Hlava, P. F. and Keil, K. (1975) Inclusions in diamonds: Garnet lherzolite and eclogite assemblages. Phys. Chem. Earth 9: 797-816.

Vartiainen, H. and Woolley, A. R. (1974) The age of the Sokli carbonatite, Finland, and some relationships of the North Atlantic alkaline igneous province. Bull. Geol. Soc. Finland 6: $81-91$.

Whitelock, T. K. (1973) The Monastery Mine kimberlite pipe. Pp. 214-217 in Lesotho kimberlites, ed. by P. H. Nixon, LNDC, Maseru, Lesotho.

Manuscript received, April 20, 1978 